\title{
ASO Author Reflections: Can Patient Selection for Cytoreductive Surgery and Hyperthermic Intraperitoneal Chemotherapy be Improved?
}

\author{
Wilhelm Graf, MD, $\mathrm{PhD}^{\mathbf{1}}$, and Helgi Birgisson, $\mathrm{MD}, \mathrm{PhD}^{\mathbf{1}}$ \\ Department of Surgical Sciences, Akademiska Sjukhuset, Uppsala University, Uppsala, Sweden
}

\section{PAST}

Despite improving median and 5-year survival in patients with peritoneal surface malignancy originating from the large bowel, a substantial proportion experience rapid disease progression after seemingly radical cytoreductive surgery (CRS) and hyperthermic intraperitoneal chemotherapy (HIPEC). Some of these patients have low Peritoneal Cancer Index (PCI). Various more or less fruitful attempts have been undertaken to predict outcome but, to date, reliable measures are insufficient. Among useful predictive tools are extent of peritoneal dissemination, signet cell differentiation, and colorectal peritoneal (COREP) score. $^{1-3}$

\section{PRESENT}

Our study identified BRAF mutation as a potential predictive tool in one-tenth of patients scheduled for CRS and HIPEC. ${ }^{4}$ In fact, no patients with BRAF mutation experienced long-term survival. Mutated KRAS did not influence survival in patients undergoing CRS and HIPEC.

ASO Author Reflections is a brief invited commentary on the article "Prognostic impact of BRAF and KRAS mutation in patients with colorectal and appendiceal peritoneal metastases scheduled for CRS and HIPEC”, Ann Surg Oncol. 2019. https://doi.org/10.1245/s10434019-07452-2.

\section{(C) The Author(s) 2019}

First Received: 15 July 2019;

Published Online: 13 September 2019

W. Graf, MD, PhD

e-mail: Wilhelm.graf@surgsci.uu.se
The predictive importance of BRAF mutation also remained in multivariate analysis adjusted for PCI, CCS, and signet cell differentiation.

\section{FUTURE}

The present results need to be verified in an independent and larger patient sample. If BRAF mutation can be confirmed to have this poor prognosis after CRS and HIPEC, BRAF-mutated subjects may need alternative therapeutic strategies, such as systemic chemotherapy or targeted therapies with BRAF inhibitors, combined with CRS and HIPEC. The efforts to select the most suitable group for CRS and HIPEC should be continued, and even increased, in view of the results of a recent controlled trial ${ }^{5}$ where unselected patients were included.

ACKNOWLEDGEMENTS Open access funding provided by Uppsala University.

DISCLOSURES Wilhelm Graf and Helgi Birgisson have no conflicts of interest to disclose.

OPEN ACCESS This article is distributed under the terms of the Creative Commons Attribution 4.0 International License (http://crea tivecommons.org/licenses/by/4.0/), which permits unrestricted use, distribution, and reproduction in any medium, provided you give appropriate credit to the original author(s) and the source, provide a link to the Creative Commons license, and indicate if changes were made.

\section{REFERENCES}

1. Goéré D, Souadka A, Faron M, Cloutier AS, Viana B, Honoré C, et al. Extent of colorectal peritoneal carcinomatosis: attempt to define a threshold above which HIPEC does not offer survival benefit: a comparative study. Ann Surg Oncol. 2015;22:2958-64.

2. Solomon D, DeNicola N, Feingold D, Liu PH, Aycart S, Golas BJ, et al.Signet ring cell features with peritoneal carcinomatosis in 
patients undergoing cytoreductive surgery and hyperthermic intraperitoneal chemotherapy are associated with poor overall survival. J Surg Oncol. 2019;119(6):758-65.

3. Cashin PH, Graf W, Nygren P, Mahteme H. Patient selection for cytoreductive surgery in colorectal peritoneal carcinomatosis using serum tumor markers: an observational cohort study. Ann Surg. 2012;256(6):1078-83.

4. Graf W, Cashin PH, Ghanipour L, Enblad M, Botling J, Terman A, et al. Prognostic impact of BRAF and KRAS mutation in patients with colorectal and appendiceal peritoneal metastases scheduled for CRS and HIPEC. Ann Surg Oncol. 2019. https://doi.org/10. 1245/s10434-019-07452-2.

5. Quenet F, Elias D, Roca L, Goere D, Ghouti L, Pocard M, et al. A UNICANCER phase III trial of hyperthermic intra-peritoneal chemotherapy (HIPEC) for colorectal peritoneal carcinomatosis (PC): PRODIGE 7 [abstract]. J Clin Oncol. 2018;36:18.

Publisher's Note Springer Nature remains neutral with regard to jurisdictional claims in published maps and institutional affiliations. 